\title{
PEMETAAN BAHAN ORGANIK TANAH PADA SAWAH IRIGASI DAN TADAH HUJAN DI KECAMATAN TUREN, MALANG
}

\section{Mapping of Soil Organic Matters in Irrigation and Rainfed Paddy Fields in Turen District, Malang}

\author{
Christanti Agustina*, Mochtar Lutfi Rayes, Novalia Kusumarini, Khanza \\ Amaladewi Sudharta \\ Jurusan Tanah, Fakultas Pertanian, Universitas Brawijaya Jl. Veteran No.1, Malang, Jawa Timur 65145 \\ *Penulis korespondensi: christanti.ag@ub.ac.id
}

\begin{abstract}
Each land use has a different vegetation density and the litter input as a source of soil organic matter. Vegetation density index can be analyzed based on the NDVI equation using the GIS approach. This study aims to determine the effect of different land uses and NDVI on soil organic matter content and the mapping of soil organic matter content. This research was conducted from April to August 2019 in Turen District, Malang Regency. The survey method used for collecting data in the field (36 observation points) based on differences in landform, relief, slope, land use (irrigated and rainfed rice fields), and vegetation density index classes (low, medium, high). Soil samples were taken at $0-20 \mathrm{~cm}$ depth and analyzed for soil organic matter content. Data interpolation using IDW was used for mapping soil organic matter. The results showed that there was a very significant effect between differences in land use and NDVI class on the content of soil organic matter $(\mathrm{p}<0.001)$. NDVI value gives an effect of $81.5 \%$ on soil organic matter content. The distribution of soil organic matter content is classified into 5 classes, which are very low, low, moderate, high and very high.
\end{abstract}

Keywords : geographic information system, landsat OLI/TIRS, NDVI, remote sensing, soil organic matter

\section{Pendahuluan}

Salah satu subsektor pertanian yang mendukung pemenuhan kebutuhan tersebut adalah sektor pertanian untuk tanaman pangan. Kecamatan Turen di Kabupaten Malang, Provinsi Jawa Timur merupakan salah satu wilayah yang memiliki lahan pertanian dengan komoditas pangan sebesar separuh luas wilayahnya, sekitar 6.640,7 ha. Komoditas pertanian yang sering dibudidayakan antara lain komoditas padi, jagung, dan tebu. Produksi komoditas pertanian khususnya tanaman pangan di Kecamatan Turen mengalami penurunan dalam kurun waktu 2013-2017, dari $16.121 \mathrm{t} / \mathrm{ha}$ menjadi 7.852 t/ha (Badan Pusat Statistik Kabupaten Malang, 2017). Penurunan hasil pertanian ini diduga karena adanya ketidakmerataan kandungan bahan organik tanah sebagai sumber unsur hara. Salah satu pemicu ketidakmerataan kandungan bahan organik tanah adalah praktek pengelolaan lahan oleh petani yang tidak sama. Pengembalian sisa panen dapat meningkatkan masukan sumber bahan organik tanah dan tidak sedikit petani yang mengangkut seluruh hasil panen (termasuk biomasaa) keluar lahan, sehingga masukan bahan organik menjadi rendah (Tangketasik et al., 2012). Akibatnya, kandungan unsur hara dari setiap lahan tidak sama dan tanaman tidak mendapat asupan unsur hara yang seragam sehingga terjadi perbedaan hasil produksi pertanian. Nita et al. (2015) mengatakan bahwa ketidak-tepatan dan adanya perbedaan dalam manajemen lahan akan berpengaruh terhadap sifat tanah baik secara 
fisik, kimia dan biologi. Yuniwati (2017) menyatakan bahwa tingkat kesuburan tanah ditentukan oleh jenis penggunaan dan pengelolaan lahannya. Lahan yang memiliki sumber masukan bahan organik mampu menyediakan kebutuhan unsur hara bagi tanaman dan meningkatkan produktivitas tanaman. Hal tersebut menjadikan bahan organik sebagai salah satu komponen tanah yang sangat erat kaitannya dengan kualitas tanah, sehingga bahan organik merupakan komponen penting dalam sistem pertanian.

Kandungan bahan organik tanah dapat diukur melalui kandungan karbon tanah. Secara spasial, penilaian kandungan bahan organik tanah pada wilayah yang luas dapat dimudahkan dengan menggunakan pendekatan dari tingkat kerapatan vegetasi (NDVI, normalized difference vegetation index) (Arrouays et al., 2001). Vegetasi merupakan salah satu sumber bahan organik tanah sehingga dapat diasumsikan bahwa semakin rapat vegetasi maka sumber bahan organik akan semakin tinggi. Karena keberadaan vegetasi di atas permukaan tanah sangat erat kaitannya dalam menghasilkan bahan organik di dalam tanah, maka untuk dapat menerapkan pengelolaan lahan yang tepat di lahan pertanian, perlu dilakukan pendekatan secara spasial untuk mempelajari sebaran bahan organik tanah.

Penelitian ini dilakukan guna mempelajari pengaruh jenis penggunaan lahan dan tingkat kerapatan vegetasi (NDVI) terhadap kandungan bahan organik tanah, serta pemanfaatan sistem informasi geografi untuk memetakan sebaran kandungan bahan organik di lapangan. Pemanfaatan sistem informasi geografi diharapkan mampu memberikan luaran berupa informasi data spasial tentang sebaran status bahan organik tanah di Kecamatan Turen.

\section{Bahan dan Metode}

\section{Tempat dan waktu penelitian}

Penelitian dilaksanakan pada April - Agustus 2019 di Kecamatan Turen, Kabupaten Malang, Provinsi Jawa Timur yang terletak pada 8॰6'48.963 - 8॰14'11.477 LS dan 112॰38'42.549 - 112046’16.821 BT. Analisis data spasial dilaksanakan di Laboratorium Pedologi dan Sistem Informasi Sumberdaya Lahan, dan analisis kandungan bahan organik tanah dilakukan di Laboratorium Kimia Tanah, Fakultas Pertanian, Universitas Brawijaya.

\section{Alat dan bahan}

Alat yang digunakan selama penelitian ini yaitu GPS (Global Positioning System), bor tanah, plastik ukuran $1 \mathrm{~kg}$, kertas label, timbangan digital, ayakan 0,5 mm, erlenmeyer, buret, alat tulis, kamera, laptop Asus X455L, Software ArcGIS 10.3 dan Software SAGA GIS. Bahan yang digunakan selama penelitian ini yaitu $\mathrm{K}_{2} \mathrm{Cr}_{2} \mathrm{O}_{7}, \mathrm{H}_{2} \mathrm{SO}_{4}, \mathrm{H}_{3} \mathrm{PO}_{4} 85 \%, \mathrm{FeSO}_{4}$, sampel tanah, Peta Rupa Bumi Indonesia skala 1:25.000 Lembar Turen 1607-432, DEM SRTM 30 m, Peta Geologi skala 1:100.000 Lembar Turen 1607-4, dan Citra Landsat 8 OLI/TIRS (Path/Row : 118/65) tanggal perekaman 18 Januari 2019.

\section{Metode}

Penelitian ini dilaksanakan dengan menggunakan metode grid bebas dengan tingkat survei semi-detail pada skala 1:50.000. Penentuan area survei pada penelitian ini mengacu pada Satuan Peta Lahan (SPL). Peta SPL diperoleh dari hasil tumpang-tindih (overlay) dari peta geologi, peta bentuk lahan (landform), peta relief, peta lereng, peta penggunaan lahan dan peta indeks kerapatan vegetasi (NDVI). Secara keseluruhan kegiatan penelitian dibagi dalam tahap pra-survei, tahap survei, tahap analisis laboratorium, tahap analisis data, dan pemetaan sebaran bahan organik tanah.

Kegiatan pra-survei diawali dengan pengumpulan data sekunder berupa data peta, antara lain: Peta Rupa Bumi Indonesia Lembar Turen 1607-432, Peta DEM SRTM 30 m, Peta Geologi skala 1:100.000 Lembar Turen, dan Citra Landsat 8 OLI/TIRS (Path/Row : 118/65) tanggal perekaman 18 Januari 2019. Kemudian dilanjutkan dengan pembuatan peta dasar, antara lain Peta Batas Administrasi diturunkan dari Peta Rupa Bumi Indonesia, Peta Bentuk Lahan diturunkan dari tampilan 3 dimensi data DEM SRTM $30 \mathrm{~m}$ dan Peta Geologi, Peta Relief dan Peta Lereng diturunkan dari data DEM SRTM $30 \mathrm{~m}$ menggunakan spatial analysts ArcGIS 10.3., Peta Penggunaan Lahan diturunkan dari Peta Rupa Bumi Indonesia, dan Peta Indeks Kerapatan Vegetasi (NDVI) diturunkan dari persamaan (1) yang 
diawali dengan proses pra-pengolahan citra dan pengolahan citra.

NDVI $=\frac{\rho \text { NIR }-\rho \text { RED }}{\rho \mathrm{NIR}+\rho \mathrm{RED}} \ldots \ldots \ldots \ldots .$. persamaan $(1)$

(Rouse et al., 1974)

Keterangan :

$$
\begin{aligned}
\text { @NIR }= & \text { nilai reflektan saluran infra } \\
& \text { merah dekat (band 5) } \\
\text { @Red }= & \text { nilai reflektan saluran merah } \\
& (\text { band } 4)
\end{aligned}
$$

Setelah disusun peta dasar, kegiatan selanjutnya adalah pembuatan Satuan Peta Lahan (SPL). Peta SPL merupakan hasil tumpeng tingih (overlay) dari Peta Geologi, Peta Bentuk Lahan (Landform), Peta Relief, Peta Lereng, Peta Penggunaan Lahan, dan Peta Indeks Kerapatan Vegetasi. Penggunaan lahan dibatasi dalam dua jenis, yaitu sawah irigasi dan tadah hujan. Peta Indeks Kerapatan Vegetasi dikelompokkan dalam tiga kelas, yaitu: kelas rendah, kelas sedang dan kelas tinggi. Penetapan titik pengamatan berdasarkan pada keragaman satuan peta lahan dan diperoleh sebanyak 36 titik pengamatan. Kegiatan survei dilakukan untuk proses pengambilan contoh tanah di lokasi penelitian. Pengambilan contoh tanah menggunakan bor tanah dengan panjang mata bor $20 \mathrm{~cm}$ pada kedalaman $0-20 \mathrm{~cm}$. Setiap contoh tanah dilakukan analisis kandungan bahan organik tanah menggunakan metode Walkley and Black (1934) dan dikelompokkan status kesuburan tanah menurut Ritung et al.
(2011), yaitu: sangat rendah $(<1 \%)$, rendah $(1-$ $2 \%)$, sedang $(2-3 \%)$, tinggi $(3-5 \%)$, dan sangat tinggi $(>5)$. Data kandungan bahan organik tanah selanjutnya dilakukan analisis statistik untuk dilakukan uji keragaman data dengan menggunakan Rancangan Acak Kelompok (RAK), uji Duncan dilakukan untuk melihat perbedaan kandungan bahan organik antar perlakuan, uji korelasi dan regresi dilakukan untuk mengetahui hubungan indeks kerapatan vegetasi dengan kandungan bahan organik. Analisis statistik memanfaatkan software GenStat Discovery Edisi 19. Selanjutnya dilakukan analisis data berdasarkan pendekatan GIS untuk menyusun sebaran kandungan bahan organik tanah. Pemetaan kandungan bahan organik tanah menggunakan metode interpolasi IDW (Inverse Distance Weighted).

\section{Hasil dan Pembahasan}

\section{Kandungan bahan organik tanah}

Hasil penelitian menunjukkan bahwa kandungan bahan organik tanah di lokasi penelitian berkisar pada kelas rendah $(1,49 \pm 0,20 \%)$ hingga tinggi $(4,57 \pm 0,20 \%)$ (Ritung et al., 2011). Berdasarkan

Tabel 1 tampak bahwa kandungan bahan organik tanah pada kelas rendah terdapat di penggunaan lahan sawah irigasi dan tadah hujan pada kelas indeks vegetasi (NDVI) rendah, kelas bahan organik sedang berada pada penggunaan lahan sawah irigasi dan tadah hujan dengan kelas NDVI sedang, dan kelas bahan organik tinggi berada pada penggunaan lahan sawah irigasi dan tadah hujan dengan kelas NDVI tinggi.

Tabel 1. Hasil pengukuran bahan organik tanah di lokasi penelitian.

\begin{tabular}{cccccc}
\hline No & $\begin{array}{c}\text { Penggunaan } \\
\text { Lahan }\end{array}$ & $\begin{array}{c}\text { Kelas } \\
\text { NDVI }\end{array}$ & $\begin{array}{c}\text { Jumlah } \\
\text { Sampel }\end{array}$ & $\begin{array}{c}\text { Kandungan Bahan } \\
\text { Organik Tanah (\%) }\end{array}$ & $\begin{array}{c}\text { Status } \\
\text { Kesuburan*) }\end{array}$ \\
\hline 1 & \multirow{2}{*}{ Sawah Irigasi } & Rendah & 9 & 1,49 & Rendah \\
2 & Sedang & 6 & 2,44 & Sedang \\
3 & & Tinggi & 12 & 4,57 & Tinggi \\
\hline 4 & \multirow{2}{*}{ Sawah Tadah } & Rendah & 3 & 1,56 & Rendah \\
5 & Sedang & 3 & 2,78 & Sedang \\
6 & Hujan & Tinggi & 3 & 3,93 & Tinggi \\
\hline
\end{tabular}

Keterangan: *) Status kesuburan tanah berdasarkan Ritung et al. (2011). 


\section{Pengaruh perbedaan penggunaan lahan dan NDVI terhadap kandungan bahan organik tanah}

Analisis ragam menunjukkan bahwa perbedaan penggunaan lahan dan kelas indeks vegetasi (NDVI) memberikan pengaruh nyata $(\mathrm{p}<0,05)$ terhadap kandungan bahan organik tanah. Kandungan bahan organik tanah pada sawah irigasi cenderung lebih tinggi $(3,07 \pm 0,20 \%)$ daripada tadah hujan $(2,76 \pm 0,20 \%)$. Hal serupa dinyatakan pula oleh Yang et al. (2019), bahwa kandungan bahan organik pada lahan yang ditanami padi cenderung lebih tinggi daripada lahan yang ditanami kapas yang berada pada lahan tadah hujan (tegalan). Hal serupa juga diperoleh oleh Tangketasik et al. (2012), bahwa kandungan bahan organik pada lahan sawah cenderung lebih tinggi daripada lahan tegalan. Kandungan bahan organik di lahan tegalan yang lebih rendah daripada sawah irigasi ini disebabkan oleh rendahnya masukan seresah dari pengembalian sisa panen ke lahan. Umumnya, petani di Kecamatan Turen mengambil sisa tanaman (jagung) untuk pakan ternak dan kayu bakar, baik sisa tanaman berupa batang, daun, maupun tongkol jagung. Yang et al. (2019) pun menyatakan hal yang sama, kandungan bahan organik yang rendah pada sistem lahan pertanian disebabkan oleh praktek pengembalian sisa panen ke lahan dalam jumlah sedikit. Kedua sistem penggunaan lahan ini memiliki kegiatan budidaya yang berbeda, jika dilihat dari segi pengolahan tanah, kegiatan pasca panen dan penerapan rotasi tanaman. Menurut Tangketasik et al. (2012), kandungan bahan organik yang lebih rendah di lahan tegalan daripada lahan sawah disebabkan oleh lahan tegalan memiliki kondisi aerasi yang lebih baik daripada lahan sawah. Kondisi aerasi dan drainase yang baik dapat mempercepat proses dekomposisi bahan organik dalam tanah daripada lahan dengan aerasi dan drainase yang buruk (lahan sawah).

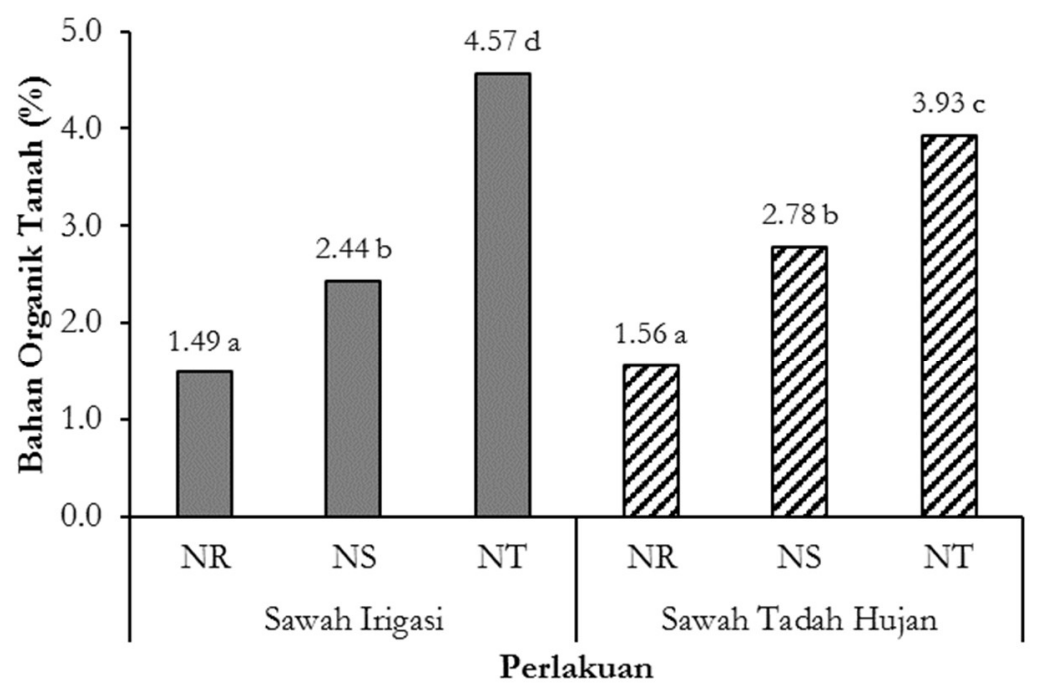

Keterangan: NR: kelas NDVI rendah; NS: kelas NDVI sedang dan NT: kelas NDVI tinggi; s.e.d = 0.12;

Notasi huruf menunjukkan terdapat perbedaan yang nyata terhadap kandungan bahan organik di setiap perlakuan (DMRT 0.05); Status bahan organik sangat rendah $(<1 \%)$, rendah (1-2\%), sedang (2-3\%), tinggi (3-5\%), sangat tinggi (>5\%), menurut Balai Penelitian Tanah (2009)

Gambar 1. Kandungan bahan organik tanah pada setiap perbedaan penggunaan lahan dan NDVI.

Kandungan bahan organik tanah pada perbedaan kelas NDVI memiliki pola kandungan bahan organik tinggi mengikuti kelas NDVI yang semakin tinggi, berurutan dari tertinggi ke terendah terdapat pada kelas NDVI tinggi, rendah, dan sedang (Gambar 1). Hubungan yang diberikan adalah semakin tinggi kelas NDVI diikuti oleh tingginya kandungan bahan organik tanah (Gambar 2). sehingga dapat dikatakan bahwa keberadaan vegetasi yang ada 
di atas permukaan tanah dapat mempengaruhi keberadaan kandungan bahan organik tanah. Selain itu, berdasarkan uji regresi guna mengetahui pengaruh NDVI terhadap kandungan bahan organik tanah memberikan pengaruh positif dengan persamaan $\mathrm{y}=8,8898 \mathrm{x}$ - 0,1563 dengan koefisien $\mathrm{R}^{2}$ adalah 0,815 atau $81,5 \%$. Pengaruh positif tersebut menunjukkan bahwa semakin tinggi nilai NDVI makan diikuti dengan peningkatan kandungan bahan organik tanah. Pada dasarnya, vegetasi yang ada diatas permukaan tanah akan memberikan sumbangan bahan organik kedalam tanah sehingga mampu memberikan dampak langsung terhadap keberaan atau ketersediaan bahan organik didalam tanah. Penelitian-penelitian sebelumnya mengatakan bahwa semakin tinggi atau rapat vegetasi yang adat diatas permukaan tanah, maka akan semakin tinggi pula kandungan bahan organik di dalam tanah. Bhunia et al. (2019a) dan Bhunia et al. (2019b) menyatakan terdapat hubungan positif antara nilai NDVI dengan kandungan bahan organik dalam tanah. Keberadaan vegetasi yang ditunjukkan dari nilai NDVI memberikan sumbangan seresah yang terdekomposisi dan meghasilkan kandungan bahan organik tanah (Luo et al., 2008).

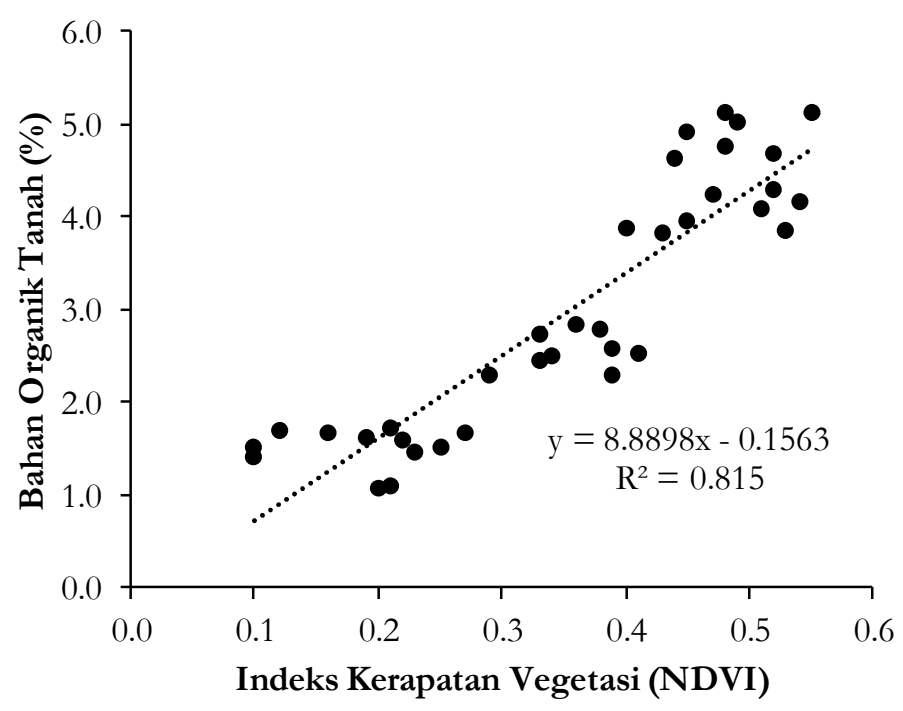

Gambar 2. Hubungan indeks kerapatan vegetasi (NDVI) dengan bahan organik tanah.

\section{Sebaran bahan organik tanah}

Hasil interpolasi data menggunakan metode IDW (Inverse Distance Weighted, Gambar 3) menunjukkan bahwa status kesuburan tanah berdasarkan kandungan bahan organik tanah dikelompokkan dalam 5 (lima) kelas, yaitu sangat rendah, rendah, sedang, tinggi, dan sangat tinggi, baik pada penggunaan lahan sawah irigasi dan tadah hujan (Ritung et al., 2011). Status kandungan bahan organik dengan kelas sangat rendah berada di Desa Sananrejo, Desa Pagedangan, Desa Gedog Wetan dan Desa Gedog Kulon, seluas 106,7 ha atau setara dengan 13,7\% dari total luasan. Sebaran dengan kelas rendah berada di Desa Sawahan, Desa Kemulan, Desa Tawangrejeni, Desa Undaan,
Desa Gedog Kulon, Desa Gedog Wetan, Desa Pagedangan dan Desa Sananrejo, seluas 272,6 ha atau 35,0\%. Kemudian kelas sedang tersebar di Desa Tumpuk Renteng, Desa Talangsuko, Desa Kedok, Desa Jeru, Desa Sananrejo, Kel. Turen, Desa Talok, Desa Undaan, Desa Gedog Wetan, Desa Gedog Kulon dan Desa Sawahan, seluas 131,9 ha atau $17,0 \%$. Selanjutnya kelas tinggi berada di Desa Gedog Wetan, Desa Gedog Kulon, Desa Sedayu, Kel. Turen, Desa Talangsuko, Desa Kedok, Desa Sananrejo, Desa Undaan dan Desa Sanankerto dengan luasan 177,8 ha atau $22,9 \%$. Kelas sangat tinggi tersebar di Desa SananKerto, Desa Tanggung, Desa Sedayu dan Desa Undaan dengan luasan 89,1 ha atau $11,5 \%$. 


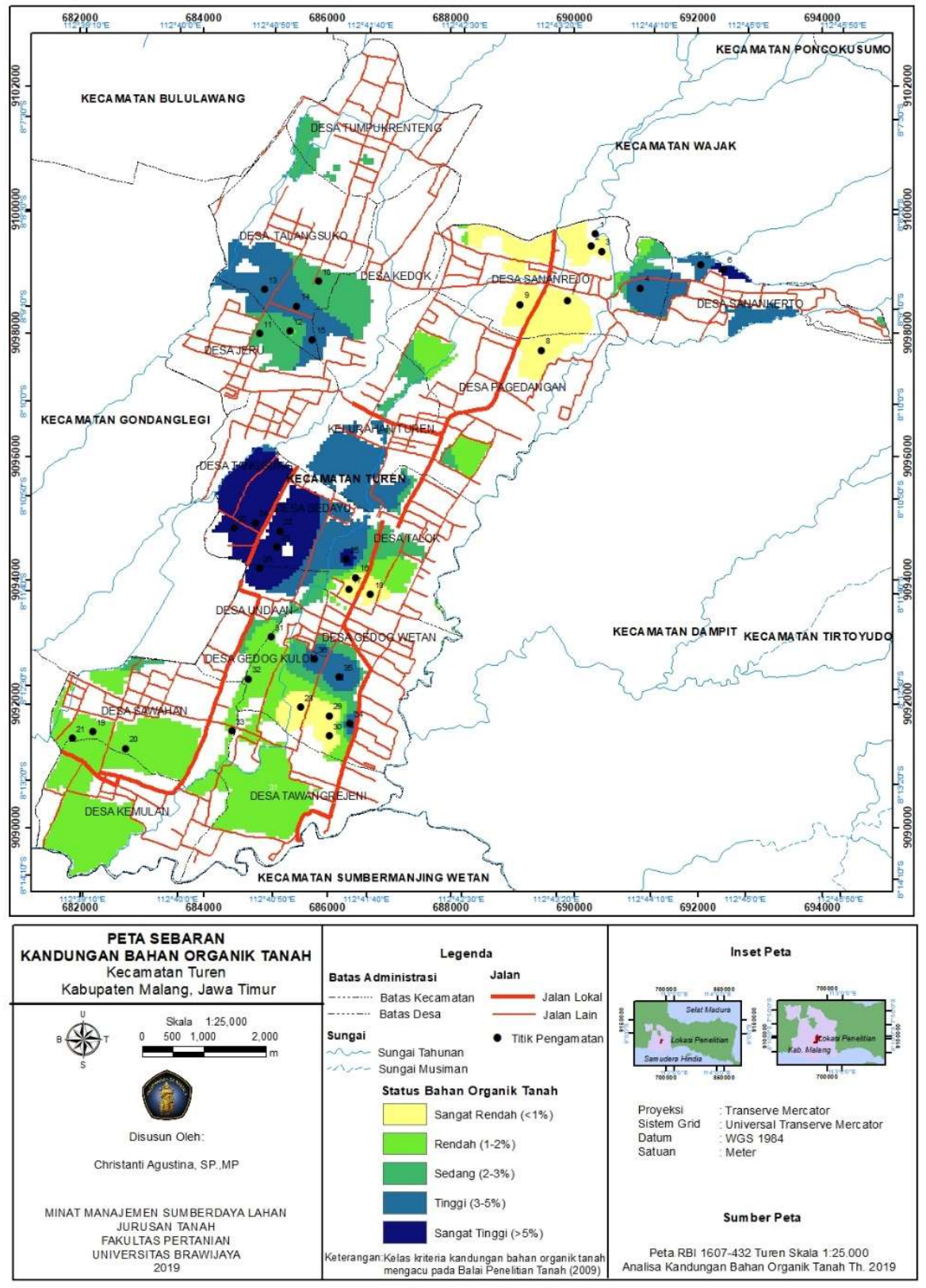

Gambar 3. Peta sebaran bahan organik tanah lokasi penelitian.

\section{Kesimpulan}

Perbedaan jenis penggunaan lahan dan indeks kerapatan vegetasi memberikan pengaruh terhadap kandungan bahan organik tanah. Kandungan bahan organik pada lahan sawah irigasi lebih tinggi daripada lahan tadah hujan. Indeks kerapatan vegetasi menentukan kandungan bahan organik dalam tanah. Semakin tinggi indeks kerapatan vegetasi, maka kandungan bahan organik tanah juga semakin tinggi. Sebaran kandungan bahan organik tanah digolongkan dalam 5 kelas sangat rendah (106,7 ha), rendah (272,6 ha), sedang (131,9 ha), tinggi (177,8 ha) dan sangat tinggi (89,1 ha).

\section{Ucapan Terima Kasih}

Terima kasih disampaikan kepada LPPM Universitas Brawijaya atas pendanaan Hibah Peneliti Pemula yang berjudul "Penilaian Status Kesuburan Tanah dengan Pendekatan Fertility Capability Class (FCC) 
pada Lahan Pertanian di Kecamatan Turen, Kabupaten Malang" melalui Dana Penerimaan Negara Bukan Pajak (PNBP) Universitas Brawijaya sesuai dengan Daftar Isian Pelaksanaan Anggaran DIPA-042.01.2.400919/2019. Penulis juga menyampaikan terima kasih kepada masyarakat di wilayah Kecamatan Turen yang telah memberikan ijin dalam pengumpulan data primer.

\section{Daftar Pustaka}

Arrouays, D., Deslais, W. and Badeau, V. 2001. The carbon content of topsoil and its geographical distribution in France. Soil Use and Management 17: 7-11.

Badan Pusat Statistik Kabupaten Malang. 2017. Kecamatan Turen dalam Angka 2017. (W. Furgandari \& R.K. Wardhani, Eds.). Malang: BPS Kabupaten Malang.

Bhunia, G.S., Shit, P.K. and Edalat, M. 2019a. Prediction of Soil Organic Carbon and its Mapping Using Regression Analyses and Remote Sensing Data in GIS and R. Spatial Modeling in GIS and $\mathrm{R}$ for Earth and Environmental Sciences, 429-450.

Bhunia, G.S., Shit, P.K. and Pourghasemi, H. R. 2019b. Soil organic carbon mapping using remote sensing techniques and multivariate regression model. Geocarto International 34(2): 215-226.

Luo, Z., Yaolin, L., Jian, W. and Jing, W. 2008. Quantitative Mapping of Soil Organic Material Using Field Spectrometer and Hyperspectral Remote Sensing. In C. Jun, J. Jie, \& A. PELED (Eds.), The International Archives Of The Photogrammetry, Remote Sensing and Spatial Information Sciences. Beijing: 3-11 Juli 2008. pp. 901-906.
Nita, C.E., Siswanto, B. dan Utomo, W.H. 2015. Pengaruh pengolahan tanah dan pemberian bahan organik (blotong dan abu ketel) terhadap porositas tanah dan pertumbuhan tanaman tebu pada Ultisol. Jurnal Tanah dan Sumberdaya Lahan 2(1): 119-127.

Ritung, S., Nugroho, K., Mulyani, A. dan Suryani, E. 2011. Petunjuk Teknis Evaluasi Lahan untuk Komoditas Pertanian (Revisi). Bogor: Balai Besar Penelitian dan Pengembangan Sumberdaya Lahan Pertanian.

Rouse, J.W. Jr., Haas, R.H., Deering, D.W., Schell, J.A. and Harlan, J.C.1974. Monitoring the Vernal Advancement and Retrogradation (Green Wave Effect) of Natural Vegetation, NASA/GSFC Type III Final Report, Greenbelt, MD., 371p.

Tangketasik, A., Wikarniti, N.M., Soniari, N.N. dan Narka, I.W. 2012. Kadar bahan organik tanah pada tanah sawah dan tegalan di Bali serta hubungannya dengan tekstur tanah. Agrotrop 2(2): 101-107.

Walkley, A. and Black, I.A. 1934. An examination of the Degtjaref method for determining soil organic matter and a proposed modification of the chromic acid titration method. Soil Science, 37, 29-38.

Yang, L., Song, M., Zhu, A-X., Qin, C., Zhou, C., Qi, F., Li, X., Chen, Z. and Gao, B. 2019. Predicting soil organic carbon content in croplands using crop rotation and Fourier transform decomposed variables. Geoderma 340: 289-302.

Yuniwati, E.D. 2017. Manajemen Tanah: Teknik Perbaikan Kualitas Tanah. Malang, Indonesia: Intimedia. 
halaman ini sengaja dikosongkan 